\title{
Heating Quality and Stability of Aqueous Enzymatic Extraction of Fatty Acid-Balanced Oil in Comparison with Other Blended Oils
}

\author{
Yang Li, ${ }^{1}$ Dan Li, ${ }^{1}$ Baokun Qi, ${ }^{1}$ Sami Rokayya, ${ }^{1,2}$ Wenjun Ma, ${ }^{1}$ Jing Liang, \\ Xiaonan Sui, ${ }^{1}$ Yan Zhang, ${ }^{1}$ and Lianzhou Jiang ${ }^{1}$ \\ ${ }^{1}$ Department of Food Science, Northeast Agricultural University, Harbin, Heilongjiang 150030, China \\ ${ }^{2}$ Department of Home Economics, Faculty of Education Quality, Mansoura University, Mansoura, Dakahlia 35516, Egypt
}

Correspondence should be addressed to Yang Li; liyanghuangyu@163.com and Lianzhou Jiang; jlzname@163.com

Received 15 February 2014; Revised 5 May 2014; Accepted 13 May 2014; Published 28 May 2014

Academic Editor: Stavros Lalas

Copyright ( 2014 Yang Li et al. This is an open access article distributed under the Creative Commons Attribution License, which permits unrestricted use, distribution, and reproduction in any medium, provided the original work is properly cited.

\begin{abstract}
The heating performance of enzyme-assisted aqueous processing-extracted blended oil (EAEPO), hexane-extracted blended oil (HEBO), and three kinds of blended oils was investigated by varying the heating times. Oil degradation was monitored by analysis of the acid value (AV), peroxide value (PV), $p$-anisidine value $(p-\mathrm{AV})$, color, and trans-fatty acid composition. The fatty acid ratios of EAEPO, HEBO, and the three kinds of blended oils were very similar $(0.27: 1.03: 0.96,0.27: 1.08: 1.16,0.27: 0.65: 0.8$, $0.27: 0.6: 0.84$, and $0.27: 0.61: 0.79$, resp.). The AV and color increased in proportion to the heating time for all the oils. There was a rapid increase in the PV and $p-A V$ of EAEPO and HEBO after heating for only $1 \mathrm{~h}$, whereas the other three blended oils showed a rapid increase after heating for $2 \mathrm{~h}$ or $6 \mathrm{~h}$. Despite the highest trans-fatty acid content found for HEBO, this content was relatively low and remained low up to a heating time of $8 \mathrm{~h}$. It was found that after heating, a fatty acid ratio relatively close to its ideal value $(0.27: 0.48: 0.49)$ was maintained by EAEPO, which indicates that EAEPO is tolerant to heat treatment and is suitable for maintaining a healthy diet.
\end{abstract}

\section{Introduction}

In recent times, the use of oils with a balanced fatty acid ratio has emerged as one of the most important concerns for maintaining a healthy diet. The blending of several oils with different characteristics is one of the simplest procedures for controlling the characteristics of edible oil [1]. The United States Recommended Dietary Allowances (RDA) and the World Health Organization (WHO) recommend the fatty acid ratio of 1 (SFA, saturated fatty acid(s)):1 (MUFA, monounsaturated fatty acid(s)):1 (PUFA, polyunsaturated fatty acid(s)) as an ideal ratio for health [2]. In addition, a report from the Chinese Nutrition Society (CNS) regarding dietary reference intakes suggested a fatty acid ratio of $0.27: 1: 1$ (SFA: MUFA: PUFA) after subtracting the daily consumption of fatty acids derived from animal fat [3]. The use of hexane-extracted blended oil (HEBO) is the main method currently used to achieve this aim. However, the hexane derived from petroleum distillates has environmental and safety issues, and thus, it is necessary to develop alternative methods of hexane extraction. Furthermore, the goal of achieving an acid-balanced oil has been realized by extracting oil from a mixture of soybean, rape seed, purple perilla, fructus cannabis, and scabish using an aqueous enzymatic method (EAEP). The oil extraction yield was maximized by applying the simplex-centroid mixture design method. This balanced fatty acid oil may be one of the major nutritional sources in the diet for maintaining human health by providing the body with unsaturated fatty acids, being particularly rich in omega-3, omega-6, and other nutritional components. However, heat treatment of oils is one of the most important methods for preparing food for human consumption worldwide [4] but may affect the shelf life and quality of the oil directly. Heating may simultaneously 
induce degradation and oxidation of oil components with the formation of products deleterious to human health. In addition, many reports concluded that the stability of individual vegetable oils against oxidation is unique, being dependent on the fatty acid composition and on the degree of unsaturation in particular $[5,6]$.

The quality characteristics of many oils, including Deglet Nour, Allig, olive, sunflower, and hydrogenated soybean oil, have been investigated $[7,8]$. Microwave heating of soybean oil induces severe quality and composition losses, primarily with more than 3 min of microwave heating [9]. Thus, the reactions that occur during heating of oil are an important concern. During heating, lipids may undergo chemical alterations due to hydrolytic and oxidative rancidity [10]. The influence of heating on the antioxidant activity of certain spice essential oils has been discussed in order to control lipid oxidation during food processing [11]. The influence of these reactions is derived from a number of products generated during heating, including volatile compounds, hydrolysis products, cyclic compounds, trans configuration compounds, polymers, and acrylamide. After the first two frying cycles, the free fatty acid content, peroxide value, and total polar materials increase, whereas the radical scavenging activity decreases [5].

In this paper, the oxidative stability of oils extracted using various techniques, including solvent and aqueous enzymatic methods, is determined. The major reaction conditions and corresponding physical and chemical alterations during heating are also studied by comparative analysis of three blended oils with fatty acid compositions similar to that of EAEPO and HEBO.

\section{Materials and Methods}

2.1. Materials. Dehulled and full-fat soybean flakes were obtained from a company in Shijiazhuang, and rape seed, purple perilla, fructus cannabis, and scabish were obtained from Anhui, Jiangsu, Guangxi, and Muyang, respectively. Three different types of oils, namely, Golden Arowana blend oil (GABO), Fook Lam Moon Grain blend oil (FGBO), and Fook Lam Moon balanced blend oil (FBBO), were obtained from a local market (RT-Mart, Harbin). Alcalase $2.4 \mathrm{~L}$ was sourced from Novo-Nordisk A/S (Bagsvaerd, Denmark). The fatty acid methyl ester (FAME) standards were obtained from Sigma-Aldrich Chemical Co. (St. Louis, MO, USA).

\subsection{Methods}

2.2.1. Extrusion Process. Water was sprayed onto the cracked soybean flakes to achieve the desired moisture content of $14.5 \%$ while tumbling the seeds in a mixer (TMV-100, China). The moisture content of $14.5 \%$ was chosen on the basis of previous work on oil extraction using EAEP [12]. The extruder $(20 \mathrm{~mm}$ screw die diameter) used in this work was manufactured by Engineering College, Northeast Agricultural University, Harbin, China. The rotational speed of the extruder was $105 \mathrm{rpm}$ and the barrel temperature was $90^{\circ} \mathrm{C}$. The extruded soybeans were immediately used for the
EAEP procedure or stored in polyethylene bags at $4^{\circ} \mathrm{C}$ in a refrigerator prior to use.

2.2.2. Enzyme-Assisted Aqueous Extraction Process (EAEP). Prior to the extraction procedure, the dehulled forms of rape seed $(31.5 \%)$, purple perilla $(11.8 \%)$, fructus cannabis (33.3\%), and scabish (21.2\%) were individually cracked and then mixed together with the extruded soybean $(2.3 \%)$. The beaker filled with the seed mixtures and additional water $(1: 6 \mathrm{w} / \mathrm{w})$ was subjected to ultrasonic treatment for $50 \mathrm{~min}$ at $55^{\circ} \mathrm{C}$ at a power of $500 \mathrm{~W}$ and then incubated at $55^{\circ} \mathrm{C}$ in a water bath; the $\mathrm{pH}$ of the slurry was adjusted to 9 by the addition of $2 \mathrm{~N} \mathrm{NaOH}$ [13]. The enzyme dosage of Alcalase $2.4 \mathrm{~L}$ was $1.85 \%$ (v/w, based on the dry weight of the samples). A continuous stirring device was used to disperse the mixture during the enzymatic hydrolysis process. The reactions were stably maintained at the temperature and $\mathrm{pH}$ stated above for $3 \mathrm{~h}$. At the end of the EAEP, the slurry was centrifuged in a $50 \mathrm{~mL}$ centrifuge tube at multiples of the force of gravity and expressed at 2,372 g (TGL-16G, China) for $30 \mathrm{~min}$ at $20^{\circ} \mathrm{C}$. Four distinct layers (oil, cream, skim, and insoluble) were obtained after the centrifugation. The upper oil layer was carefully collected using a Pasteur pipette, and the remaining oil adhering to the cream surface was washed twice with hexane. The hexane was removed by evaporation in a fume hood.

2.2.3. Hexane Extraction (HE) Process. The blending flakes (100 g) (extruded soybean $2.3 \%$, dehulled rape seed $31.5 \%$, dehulled purple perilla $11.8 \%$, dehulled fructus cannabis $33.3 \%$, and dehulled scabish $21.2 \%$ ) were placed in a Soxhlet extractor equipped with a $0.5 \mathrm{~L}$ round-bottom flask and a water condenser. The extraction was carried out on a water bath for $6 \mathrm{~h}$ using $3 \mathrm{~L}$ of $n$-hexane. After the extraction, hexane was removed under reduced pressure using a vacuum rotary evaporator (R205, China) at $45^{\circ} \mathrm{C}$. The recovered oil was stored under refrigeration $\left(4^{\circ} \mathrm{C}\right)$ prior to use.

2.2.4. Heat Treatment. To simulate conventional times used in cooking, the heating period was varied as $1,2,4,6$, and $8 \mathrm{~h}$. For each oil type and time, three subsamples of $80 \mathrm{~mL}$ were, respectively, placed in a domestic electronic heater plate with an intelligent magnetic stirrer (ZNCL, China) and the samples were heated at $200^{\circ} \mathrm{C}$. Unheated samples of each oil type were used as controls (corresponding to $0 \mathrm{~h}$ ). After heating, samples were stored in a brown bottle in a refrigerator $\left(4^{\circ} \mathrm{C}\right)$ prior to analysis.

\subsection{Oil Quality Analysis}

2.3.1. Determination of Fatty Acid and Trans-Fatty Acid Compositions. The trans-fatty acid composition of the oil types was analyzed using a gas chromatograph connected to a mass spectrometer (GC-MS). The fatty acid methyl esters were prepared in two steps: the oils were first saponified with $0.5 \mathrm{M} \mathrm{KOH}$ and subsequently methylated with $40 \%$ $\mathrm{BF}_{3}$ in methanol. The separation was performed using an HP-88 capillary column $(100 \mathrm{~mm} \times 0.25 \mathrm{~mm}$ i.d., $0.2 \mu \mathrm{m}$ 
film thickness; Agilent Technologies, USA) connected to a GC/MS (6890/5973, USA). The operating conditions were as follows: carrier gas pressure, $100 \mathrm{kPa}$; carrier gas, helium; split ratio, $1: 30$; injection temperature, $250^{\circ} \mathrm{C}$; scanning scope, 50 $550 \mathrm{amu}$; and ionization voltage, $70 \mathrm{eV}$. The oven temperature settings were programmed as follows: the temperature was held at $80^{\circ} \mathrm{C}$ for $5 \mathrm{~min}$, increased to $150^{\circ} \mathrm{C}$ at $10^{\circ} \mathrm{C} / \mathrm{min}$ and held at $150^{\circ} \mathrm{C}$ for $2 \mathrm{~min}$, then increased continuously to $230^{\circ} \mathrm{C}$ at a rate of $5^{\circ} \mathrm{C} / \mathrm{min}$, and held for $10 \mathrm{~min}$. The individual fatty acids were identified by comparing their retention times with standards [2].

2.3.2. Determination of Acid Value, p-Anisidine Value, and Color. The acid value was determined according to a literature method (AOAC, Cd-63), where $125 \mathrm{~mL}$ of the neutralized solvent mixture and $2 \mathrm{~mL}$ phenolphthalein indicator solution were placed into an Erlenmeyer flask and neutralized with alkali to a faint but permanent pink color. The oil sample was then weighed $(20 \pm 0.05 \mathrm{~g})$ and added to the solution, and the sample was shaken vigorously while titrating with standard alkali to the first permanent pink color of the same intensity as that of the neutralized solvent before the latter was added to the sample.

The $p$-anisidine value of the oxidized oil from fried dough after storage was determined according to the AOCS Recommended Practice Ti la-64 (AOCS, 1990).

An accurately measured amount of oil $(100 \mathrm{mg})$ was dissolved in $25 \mathrm{~mL}$, and the absorbance was measured at $350 \mathrm{~nm}$ using a UV-vis spectrophotometer (1600PC, China). This solution $(2.5 \mathrm{~mL})$ was combined with $0.5 \mathrm{~mL}$ of $0.5 \%$ $(\mathrm{w} / \mathrm{v}) \mathrm{p}$-anisidine in acetic acid, and the absorbance was read at $350 \mathrm{~nm}$ after $10 \mathrm{~min}$.

The color was determined using a Lovibond Tintometer (WSL-2, China) in the transmittance mode and expressed as red $(\mathrm{R})$ and yellow $(\mathrm{Y})$ values.

2.3.3. Determination of Peroxide Value. An accurately measured amount of oil $(300 \mathrm{mg})$ was dissolved in $9.9 \mathrm{~mL}$ of chloroform/methanol $(7: 3, \mathrm{v} / \mathrm{v})$ after which $50.0 \mu \mathrm{L}$ of $10 \mathrm{mM}$ xylenol orange and $50.0 \mu \mathrm{L}$ of iron(III) chloride solution were added [14]. The mixture solution was incubated at room temperature for $5 \mathrm{~min}$ and then centrifuged at $1000 \mathrm{~g}$ for $5 \mathrm{~min}$ at $5^{\circ} \mathrm{C}$. The supernatant was used for measurement of the absorbance at $560 \mathrm{~nm}$ using a UV-vis spectrophotometer (model 1600 PC, China). The iron(III) chloride solution was used to construct a standard curve.

2.3.4. Statistical Analysis. Data from replicate analyses of all samples were subjected to a variance analysis (ANOVA) test using SPSS 18.0 for Windows. The significant difference between the means was determined by Duncan's New Multiple Range Test $(P<0.05)$.

\section{Results and Discussion}

3.1. Changes in Acid Value. The acid value is considered in the food industry as an indicator of the quality of the oil and the degree of its degradation during heating. An increase in the

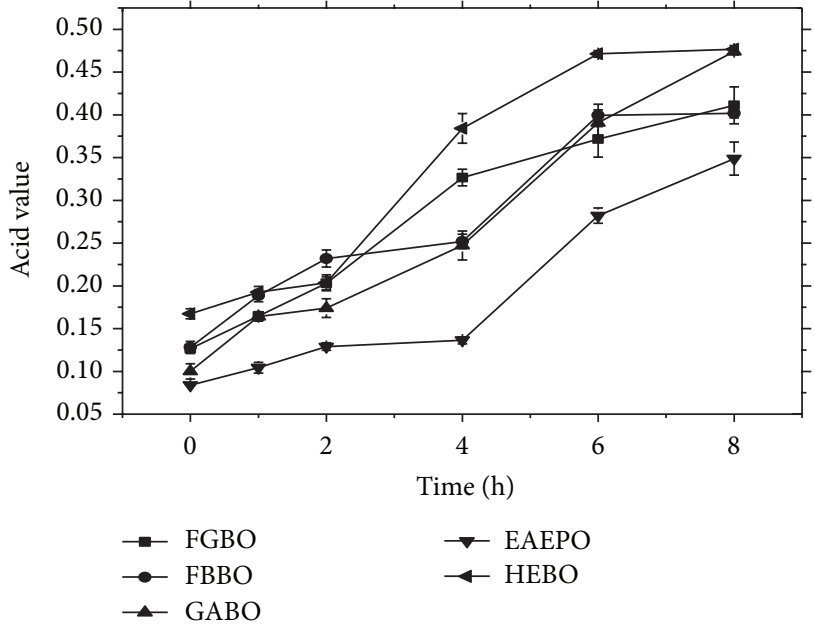

FIGURE 1: Changes in acid value.

acid value leads to the development of unpleasant tastes and odors in oils. Although the initial acid values of the oils varied from 0.08 (EAEPO) to 0.16 (HEBO) as shown in Figure 1, at the end of the heating period $(8 \mathrm{~h})$, the overall change in the acid value was found to be lowest in the case of EAEPO (0.35), followed by FBBO, FGBO, and GABO. The overall change in the acid value was highest for HEBO (0.48). This variation may be due to differences in the extraction method used. Enzymatic extraction offers the advantages of requiring a lower temperature and not requiring explosive solvents or generating harmful waste relative to solvent extraction. These results are in agreement with the values previously reported for corn oil [15].

The results also indicated a significant increase in the acid value of the various oil types as heating progressed, which may be attributed to the hydrolysis of TAG and/or cleavage and oxidation of fatty acid double bonds [16]. In addition, the low acid value of the three types of blended oils relative to HEBO might be due to the refining of the former oils. It is recognized that the free fatty acids (FFAs) are removed by saponification; thus, smaller amounts of FFAs are expected for refined oils [17]. However, the lowest acid content of the EAEPO sample might be related to its ideal fatty acid ratio. In a similar study, the stability of soybean and canola oils, with modified fatty acid composition, toward frying was evaluated. The amount of free fatty acids generated during frying was significantly less than that of the corresponding unmodified oils after $5 \mathrm{~h}$ of frying [18].

3.2. Changes in Peroxide Value $(P V)$. Figure 2 shows the changes in the PV of the oils with heating from $0 \mathrm{~h}$ to $8 \mathrm{~h}$. Prior to the heating process, EAEPO presented the lowest peroxide value $\left(3.18 \mathrm{mEq} \mathrm{O}_{2} / \mathrm{kg}\right)$, followed by $\mathrm{HEBO}$ $\left(3.51 \mathrm{mEqO}_{2} / \mathrm{kg}\right), \quad \mathrm{FGBO}\left(3.65 \mathrm{mEq} \mathrm{O}_{2} / \mathrm{kg}\right)$, and $\mathrm{FBBO}$ $\left(3.77 \mathrm{mEq} \mathrm{O}_{2} / \mathrm{kg}\right)$. The highest $\mathrm{PV}$ was detected for $\mathrm{GABO}$ $\left(3.88 \mathrm{mEq} \mathrm{O}_{2} / \mathrm{kg}\right)$. The PV of all the samples was within the acceptable limit of below $10 \mathrm{mEq} \mathrm{O}_{2} / \mathrm{kg}$ for vegetable oils [18]. In addition, the lowest PV of EAEPO is plausibly due 


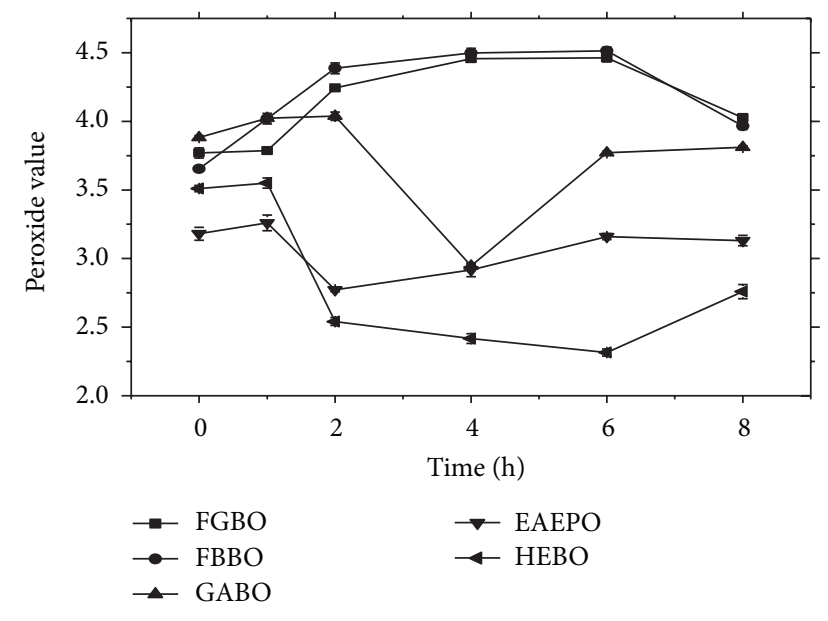

Figure 2: Changes in peroxide value.

to tocopherol release during the EAEP, which is related to hydrolysis by the enzymes [19].

The peroxide levels of all of the oil types remained similar to the original values during heating with slight variations from the initial amounts $\left(2-4 \mathrm{mEq} \mathrm{O}_{2} / \mathrm{kg}\right)$ due to the volatile nature of peroxides [17]. However, the concentration of peroxides in the various oil types differed significantly.

The PV of the EAEPO and HEBO samples increased during the first $1 \mathrm{~h}$, followed by a decline to the initial levels (3.63 $\mathrm{mEq} \mathrm{O}_{2} / \mathrm{kg}$ and $2.76 \mathrm{mEq} \mathrm{O}_{2} / \mathrm{kg}$, resp.). In the case of FGBO and FBBO, the PV continued to increase up to $6 \mathrm{~h}$ with an eventual return to the initial levels of ca. $4.02 \mathrm{mEq} \mathrm{O}_{2} / \mathrm{kg}$ and $3.96 \mathrm{mEq} \mathrm{O}_{2} / \mathrm{kg}$, respectively. The peroxide value of GABO increased to $3.81 \mathrm{mEq} \mathrm{O}_{2} / \mathrm{kg}$ after $2 \mathrm{~h}$. The rapid increase in the PV of the EAEPO and HEBO samples indicates that these oils were unstable to oxidative degradation. The EAEPO and HEBO samples had the highest percentage of polyunsaturated fatty acids and demonstrated less stability to oxidation, which is in agreement with the data previously reported for olive oil [17]. The PV decreased after reaching a maximum for all of the oil types, which is attributed to the fact that primary oxidation reactions cause an increase in the concentration of peroxides to a maximum value, beyond which the peroxide concentration decreases due to thermal decomposition thereof into secondary products [20].

3.3. Changes in $p$-Anisidine Value $(p-A V)$. The $p-A V$ is a measure of the content of aldehydes (principally 2-alkenals and 2, 4-alkadienals), which are relatively stable, and is thus a useful tool for monitoring the oxidative state of oil during heating. Therefore, for an accurate estimation of the oxidation status of the oils, both the PV and $p$-AV should be interpreted simultaneously.

Figure 3 shows the changes in the $p$-AV of the oils with heating from $0 \mathrm{~h}$ to $8 \mathrm{~h}$. The $p$-AV of all oil types increased with time. Furthermore, the $p$-AV of all the oil types exhibited significant changes at the same heating time.

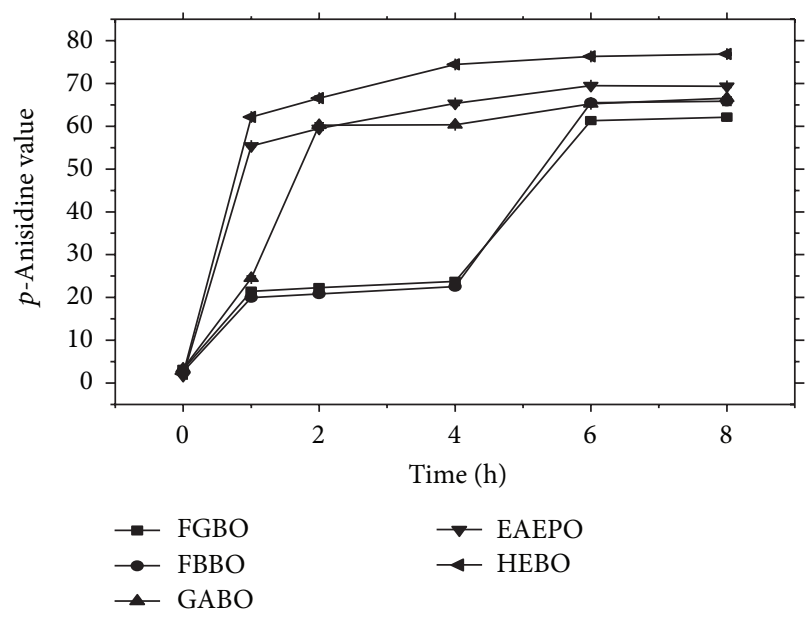

Figure 3: Changes in $p$-anisidine value.

This may be attributed to further decomposition of the lessstable primary oxidative products (hydroperoxides) to form aldehydic compounds, as previously reported [17, 21].

It was also noted that the trend in the variation of the $p$-AV with heating for FGBO was similar to that for FBBO with a maximum rate of change at $6 \mathrm{~h}$ of treatment compared to $\mathrm{GABO}$ for which the maximum rate of change was achieved at $2 \mathrm{~h}$. However, in the case of EAEPO and HEBO, rapid hydroperoxide formation was detected after $1 \mathrm{~h}$ of heat treatment, probably due to the high amounts of PUFA in the two oils. The slightly higher $p$-AV of HEBO may be due to the ability of the solvent to extract other lipid associated substances such as sterols, fat soluble compounds, and hydrocarbons. This increased $p$-AV level was consistent with the PV data presented in Figure 2, which confirms that EAEPO and HEBO present minor resistance to oxidation under heating conditions relative to the other three blended oils.

3.4. Changes in Color. Color is an important food evaluation indicator for rapid monitoring of the quality of heated oil. For the unheated oils, HEBO had the highest $\mathrm{R}$ parameter of 34.97 compared to the other blended oils due to the extraction of pigments by the organic solvent. The yellow color of EAEPO was more prominent than that of the other blended oils (55.01), indicative of the presence of more yellow pigments, such as carotenoids, in the EAEPO sample (Tables 1 and 2). However, the lighter color of the other three oils is related to decolorization during oil refining.

Heat treatment induced a considerable increase in the $\mathrm{R}$ and $\mathrm{Y}$ parameters. In general, the reddish and yellowish coloration intensifies when the pigments developed during oxidation and thermal decomposition of fatty acids diffuse into the oil during heating. In addition, these changes may also be due to traces of carotenoids [22]. The difference in the $\mathrm{R}$ parameter of the nontreated and treated oils was slightly higher (34.97 versus 39.72 ) in the case of HEBO, 
TABLE 1: Variation of yellow color of blended oils.

\begin{tabular}{lcccccc}
\hline & & & & $Y$ & & \\
& $0 \mathrm{~h}$ & $1 \mathrm{~h}$ & $2 \mathrm{~h}$ & $4 \mathrm{~h}$ & $6 \mathrm{~h}$ & $8 \mathrm{~h}$ \\
\hline FGBO & $15.08 \pm 0.14 \mathrm{aB}$ & $15.53 \pm 0.09 \mathrm{bB}$ & $15.94 \pm 0.05 \mathrm{cB}$ & $16.09 \pm 0.04 \mathrm{cB}$ & $16.37 \pm 0.03215 \mathrm{~dB}$ & $16.65 \pm 0.08 \mathrm{eB}$ \\
FBBO & $19.70 \pm 0.02 \mathrm{aC}$ & $20.17 \pm 0.03 \mathrm{bC}$ & $20.25 \pm 0.03 \mathrm{bC}$ & $20.39 \pm 0.08 \mathrm{cC}$ & $20.60 \pm 0.02082 \mathrm{dC}$ & $20.87 \pm 0.04 \mathrm{eC}$ \\
$\mathrm{GABO}$ & $29.29 \pm 0.05 \mathrm{aD}$ & $29.49 \pm 0.06 \mathrm{bD}$ & $29.87 \pm 0.08 \mathrm{cD}$ & $30.09 \pm 0.01 \mathrm{dD}$ & $30.26 \pm 0.06110 \mathrm{dD}$ & $30.57 \pm 0.09 \mathrm{eD}$ \\
EAEPO & $55.01 \pm 0.09 \mathrm{aE}$ & $55.32 \pm 0.03 \mathrm{bE}$ & $55.37 \pm 0.07 \mathrm{bE}$ & $55.80 \pm 0.09 \mathrm{cE}$ & $55.85 \pm 0.07000 \mathrm{cdE}$ & $56.05 \pm 0.07 \mathrm{eE}$ \\
HEBO & $2.13 \pm 0.09 \mathrm{aA}$ & $2.74 \pm 0.03 \mathrm{bA}$ & $3.07 \pm 0.03 \mathrm{cA}$ & $3.07 \pm 0.06 \mathrm{dA}$ & $3.52 \pm 0.02517 \mathrm{dA}$ & $3.78 \pm 0.02 \mathrm{eA}$ \\
\hline
\end{tabular}

Mean values within each row followed by different letters $(\mathrm{a}, \mathrm{b}, \mathrm{c}$, etc.) are significantly $(P<0.05)$ different. Mean values within each column followed by different letters $(\mathrm{A}, \mathrm{B}, \mathrm{C}$, etc.) are significantly $(P<0.05)$ different.

TABLE 2: Variation of red color of blended oils.

\begin{tabular}{lcccccc}
\hline & & \multicolumn{3}{c}{$\mathrm{R}$} & & \\
& $0 \mathrm{~h}$ & $1 \mathrm{~h}$ & $2 \mathrm{~h}$ & $4 \mathrm{~h}$ & $8 \mathrm{~h}$ \\
\hline FGBO & $1.21 \pm 0.02 \mathrm{aA}$ & $1.57 \pm 0.11 \mathrm{bA}$ & $2.00 \pm 0.06 \mathrm{cA}$ & $2.56 \pm 0.06 \mathrm{~dB}$ & $2.79 \pm 0.04 \mathrm{eC}$ & $3.50 \pm 0.09 \mathrm{fB}$ \\
FBBO & $1.49 \pm 0.02 \mathrm{aC}$ & $1.87 \pm 0.04 \mathrm{bC}$ & $2.00 \pm 0.05 \mathrm{bcA}$ & $2.07 \pm 0.11 \mathrm{cA}$ & $2.63 \pm 0.07 \mathrm{cB}$ & $2.76 \pm 0.04 \mathrm{dA}$ \\
GABO & $1.37 \pm 0.04 \mathrm{aB}$ & $1.77 \pm 0.04 \mathrm{bB}$ & $1.97 \pm 0.04 \mathrm{cA}$ & $2.04 \pm 0.04 \mathrm{cdA}$ & $2.15 \pm 0.04 \mathrm{dA}$ & $4.11 \pm 0.109 \mathrm{eC}$ \\
EAEPO & $2.57 \pm 0.05 \mathrm{aD}$ & $3.60 \pm 0.03 \mathrm{bD}$ & $3.64 \pm 0.02 \mathrm{bB}$ & $4.55 \pm 0.05 \mathrm{cC}$ & $4.67 \pm 0.02 \mathrm{cD}$ & $5.86 \pm 0.04 \mathrm{dD}$ \\
HEBO & $34.97 \pm 0.03 \mathrm{aE}$ & $38.03 \pm 0.09 \mathrm{bE}$ & $38.27 \pm 0.07 \mathrm{bC}$ & $38.90 \pm 0.11 \mathrm{cD}$ & $39.37 \pm 0.05 \mathrm{dE}$ & $39.72 \pm 0.10 \mathrm{eE}$ \\
\hline
\end{tabular}

Mean values within each row followed by different letters $(\mathrm{a}, \mathrm{b}, \mathrm{c}$, etc.) are significantly $(P<0.05)$ different. Mean values within each column followed by different letters $(\mathrm{A}, \mathrm{B}, \mathrm{C}$, etc.) are significantly $(P<0.05)$ different.

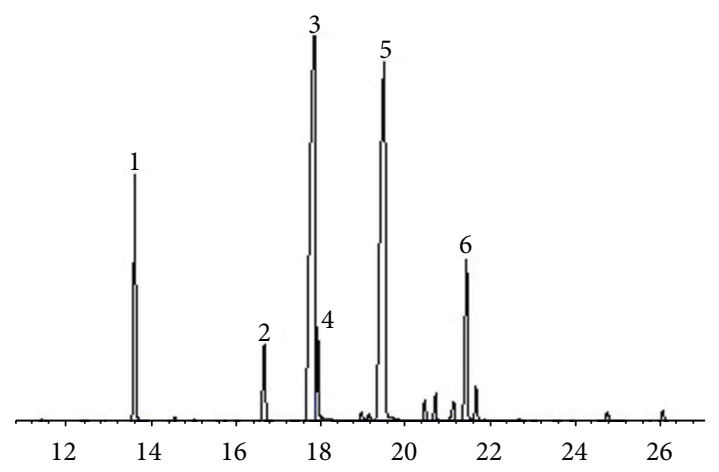

FIGURE 4: Typical chromatogram of fatty acid methyl ester prepared from EAEPO before heating. Peaks: 1: hexadecanoic acid; 2: octadecanoic acid; 3: 9-octadecenoic acid; 4: 9-octadecenoic acid; 5: 9,12octadecadienoic acid; 6: 12,15-octadecadienoic acid.

which is more sensitive to oxidation due to its higher relative percentage of PUFA. This also holds for EAEPO (2.57 versus 5.86).

3.5. Changes in Fatty Acids Composition. The fatty acid composition is the most important oil constituent parameter, and the nature of these fatty acids, particularly the degree of unsaturation, determines the oxidative stability of the oils. The unheated oils comprised four major fatty acids: palmitic, stearic, oleic, and linoleic acids (Table 3, Figure 4). The oleic acid content (40.49-47.35\%) was found to be the highest, followed by linoleic acid, (35.17-44.63\%), palmitic acid (6.61$12.12 \%)$, and stearic acid (3.14-9.15\%). EAEPO and HEBO, respectively, had the highest linoleic acid content $(40.46 \%$,

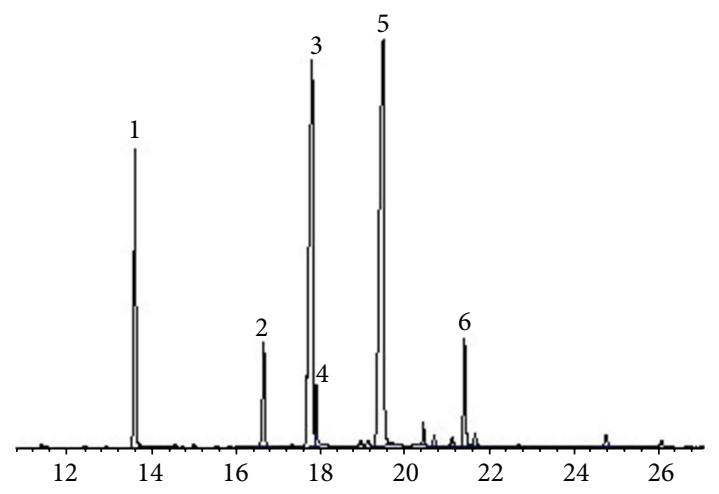

FIGURE 5: Typical chromatogram of fatty acid methyl ester prepared from EAEPO after heating. Peaks: 1: hexadecanoic acid; 2: octadecanoic acid; 3: 9-octadecenoic acid; 4: 9-octadecenoic acid; 5: 9,12octadecadienoic acid; 6: 12,15-octadecadienoic acid.

44.63\%) and the lowest palmitic acid content (7.60\%, 6.61\%). After heating for $4 \mathrm{~h}$, the palmitic acid and stearic acid contents of EAEPO increased significantly, whereas the content of oleic and linoleic acids decreased (Figure 5). Both linoleic acid and palmitic acid are considered as good indicators of the extent of fat deterioration given that linoleic acid is more susceptible to oxidation, whereas palmitic acid is more stable toward oxidation [23].

Table 4 shows the variation of the content of SFA, MUFA, and PUFA of the oils from the initial to the final heating time. Heat treatment induced a decrease in the relative percentages of the unsaturated fatty acids and an increase of the relative percentages of the saturated fatty acids, as has previously been demonstrated in various studies [17]. Progressive heating may 
TABLE 3: Main fatty acids (\%) profile.

\begin{tabular}{|c|c|c|c|c|c|c|c|}
\hline & & \multicolumn{6}{|c|}{ FAs } \\
\hline & & $0 \mathrm{~h}$ & $1 \mathrm{~h}$ & $2 \mathrm{~h}$ & $4 \mathrm{~h}$ & $6 \mathrm{~h}$ & $8 \mathrm{~h}$ \\
\hline \multirow{5}{*}{$C_{16: 0}$} & FGBO & $9.87 \pm 0.03 \mathrm{aD}$ & $17.25 \pm 0.03 \mathrm{bB}$ & $17.70 \pm 0.01 \mathrm{bcB}$ & $17.48 \pm 0.01 \mathrm{cB}$ & $17.48 \pm 0.35 \mathrm{cB}$ & $18.05 \pm 0.02 \mathrm{~dB}$ \\
\hline & FBBO & $9.15 \pm 0.02 \mathrm{aC}$ & $12.41 \pm 0.03 \mathrm{bC}$ & $13.07 \pm 0.02 \mathrm{cE}$ & $13.14 \pm 0.03 \mathrm{dD}$ & $13.71 \pm 0.03 \mathrm{eD}$ & $16.42 \pm 0.04 \mathrm{fD}$ \\
\hline & GABO & $12.12 \pm 0.02 \mathrm{aE}$ & $13.12 \pm 0.02 \mathrm{bD}$ & $17.11 \pm 0.04 \mathrm{cD}$ & $17.76 \pm 0.04 \mathrm{dE}$ & $17.76 \pm 0.01 \mathrm{dE}$ & $17.74 \pm 0.02 \mathrm{dC}$ \\
\hline & EAEPO & $7.60 \pm 0.02 \mathrm{aB}$ & $15.50 \pm 0.04 \mathrm{bE}$ & $16.32 \pm 0.01 c \mathrm{C}$ & $16.71 \pm 0.02 \mathrm{dA}$ & $16.78 \pm 0.02 \mathrm{eA}$ & $16.89 \pm 0.02 \mathrm{fA}$ \\
\hline & HEBO & $6.61 \pm 0.04 \mathrm{aA}$ & $15.92 \pm 0.01 \mathrm{bA}$ & $16.03 \pm 0.02 \mathrm{cA}$ & $17.22 \pm 0.02 \mathrm{dC}$ & $17.31 \pm 0.02 \mathrm{eC}$ & $18.15 \pm 0.01 \mathrm{fE}$ \\
\hline \multirow{5}{*}{$C_{18: 0}$} & FGBO & $4.10 \pm 0.010 \mathrm{aC}$ & $6.37 \pm 0.02 \mathrm{bD}$ & $7.14 \pm 0.03 \mathrm{cD}$ & $7.60 \pm 0.02 \mathrm{dD}$ & $7.53 \pm 0.13 \mathrm{dC}$ & $9.07 \pm 0.02 \mathrm{eC}$ \\
\hline & FBBO & $9.15 \pm 0.011 \mathrm{aE}$ & $12.41 \pm 0.03 \mathrm{bE}$ & $13.05 \pm 0.02 \mathrm{cE}$ & $13.13 \pm 0.03 \mathrm{dE}$ & $13.75 \pm 0.01 \mathrm{eD}$ & $16.44 \pm 0.00 \mathrm{fD}$ \\
\hline & GABO & $4.54 \pm 0.047 \mathrm{cD}$ & $4.15 \pm 0.04 \mathrm{bC}$ & $4.21 \pm 0.00 \mathrm{bC}$ & $4.05 \pm 0.01 \mathrm{aC}$ & $4.07 \pm 0.02 \mathrm{aB}$ & $4.56 \pm 0.04 \mathrm{cB}$ \\
\hline & EAEPO & $3.60 \pm 0.030 \mathrm{cB}$ & $3.46 \pm 0.03 \mathrm{aB}$ & $3.12 \pm 0.00 \mathrm{~dB}$ & $3.48 \pm 0.01 \mathrm{aB}$ & $3.54 \pm 0.01 \mathrm{bA}$ & $3.59 \pm 0.00 \mathrm{cA}$ \\
\hline & HEBO & $3.14 \pm 0.036 \mathrm{aA}$ & $3.23 \pm 0.020 \mathrm{bA}$ & $3.12 \pm 0.01 \mathrm{aA}$ & $3.36 \pm 0.01 \mathrm{cA}$ & $3.44 \pm 0.02 \mathrm{dA}$ & $3.61 \pm 0.02 \mathrm{eA}$ \\
\hline \multirow{5}{*}{$C_{18: 1}$} & FGBO & $46.74 \pm 0.036 \mathrm{fD}$ & $40.90 \pm 0.02 \mathrm{dD}$ & $40.54 \pm 0.04 \mathrm{cD}$ & $40.09 \pm 0.02 \mathrm{bC}$ & $41.21 \pm 0.03 \mathrm{eD}$ & $40.02 \pm 0.02 \mathrm{aC}$ \\
\hline & FBBO & $47.35 \pm 0.025 \mathrm{fE}$ & $46.53 \pm 0.04 \mathrm{eE}$ & $45.75 \pm 0.01 \mathrm{cE}$ & $46.13 \pm 0.03 \mathrm{dE}$ & $44.87 \pm 0.02 \mathrm{bE}$ & $42.62 \pm 0.04 \mathrm{aE}$ \\
\hline & GABO & $45.81 \pm 0.032 \mathrm{eC}$ & $39.79 \pm 0.02 \mathrm{aC}$ & $39.99 \pm 0.12 b C$ & $40.21 \pm 0.03 \mathrm{cD}$ & $40.55 \pm 0.04 \mathrm{dC}$ & $40.30 \pm 0.03 c D$ \\
\hline & EAEPO & $44.49 \pm 0.036 \mathrm{fB}$ & $37.91 \pm 0.03 \mathrm{eB}$ & $35.12 \pm 0.02 \mathrm{dA}$ & $34.67 \pm 0.06 \mathrm{cA}$ & $34.37 \pm 0.04 \mathrm{bA}$ & $34.28 \pm 0.02 \mathrm{aA}$ \\
\hline & HEBO & $40.49 \pm 0.025 \mathrm{fA}$ & $35.79 \pm 0.03 \mathrm{eA}$ & $35.45 \pm 0.01 \mathrm{~dB}$ & $35.23 \pm 0.02 \mathrm{cB}$ & $34.94 \pm 0.02 \mathrm{bB}$ & $34.84 \pm 0.03 \mathrm{aB}$ \\
\hline \multirow{5}{*}{$C_{18: 2}$} & FGBO & $36.34 \pm 0.025 \mathrm{fB}$ & $30.79 \pm 0.03 \mathrm{eA}$ & $30.51 \pm 0.04 \mathrm{dA}$ & $30.18 \pm 0.03 \mathrm{cA}$ & $29.97 \pm 0.03 \mathrm{bA}$ & $27.79 \pm 0.03 \mathrm{aA}$ \\
\hline & FBBO & $35.17 \pm 0.015 \mathrm{dA}$ & $33.58 \pm 0.03 \mathrm{cB}$ & $32.40 \pm 0.02 \mathrm{aB}$ & $32.37 \pm 0.08 \mathrm{aB}$ & $33.24 \pm 0.03 \mathrm{bC}$ & $32.35 \pm 0.02 \mathrm{aA}$ \\
\hline & GABO & $35.57 \pm 0.05 \mathrm{cA}$ & $36.30 \pm 0.53 \mathrm{dC}$ & $32.22 \pm 0.037 \mathrm{abB}$ & $32.60 \pm 0.07 \mathrm{bC}$ & $32.40 \pm 0.02 \mathrm{abB}$ & $32.05 \pm 0.03 \mathrm{aA}$ \\
\hline & EAEPO & $40.46 \pm 0.55 b C$ & $39.51 \pm 0.03 \mathrm{aD}$ & $39.63 \pm 0.03 \mathrm{aC}$ & $39.72 \pm 0.06 \mathrm{aE}$ & $39.74 \pm 0.02 \mathrm{aE}$ & $39.82 \pm 0.04 \mathrm{aB}$ \\
\hline & HEBO & $44.63 \pm 0.01 \mathrm{eD}$ & $39.96 \pm 0.01 \mathrm{cE}$ & $40.20 \pm 0.01 \mathrm{dD}$ & $38.97 \pm 0.02 \mathrm{bD}$ & $38.94 \pm 0.02 \mathrm{bD}$ & $38.68 \pm 0.04 \mathrm{aB}$ \\
\hline
\end{tabular}

Mean values within each row followed by different letters $(\mathrm{a}, \mathrm{b}, \mathrm{c}$, etc.) are significantly $(P<0.05)$ different. Mean values within each column followed by different letters $(\mathrm{A}, \mathrm{B}, \mathrm{C}$, etc.) are significantly $(P<0.05)$ different.

TABLE 4: Changes in saturated, monounsaturated, and polyunsaturated fatty acids.

\begin{tabular}{|c|c|c|c|c|c|c|c|}
\hline & & \multicolumn{6}{|c|}{ SFA, MUFA, and PUFA } \\
\hline & & $0 \mathrm{~h}$ & $1 \mathrm{~h}$ & $2 \mathrm{~h}$ & $4 \mathrm{~h}$ & $6 \mathrm{~h}$ & $8 \mathrm{~h}$ \\
\hline \multirow{5}{*}{ SFA } & FGBO & $15.28 \pm 0.04 \mathrm{aC}$ & $26.83 \pm 0.04 \mathrm{bE}$ & $27.75 \pm 0.01 \mathrm{cE}$ & $28.94 \pm 0.03 \mathrm{dD}$ & $27.87 \pm 0.04 \mathrm{eE}$ & $31.45 \pm 0.01 \mathrm{fE}$ \\
\hline & FBBO & $15.51 \pm 0.04 \mathrm{aD}$ & $18.34 \pm 0.02 \mathrm{bA}$ & $19.92 \pm 0.02 \mathrm{cA}$ & $19.85 \pm 0.04 \mathrm{dA}$ & $20.22 \pm 0.02 \mathrm{eA}$ & $25.32 \pm 0.01 \mathrm{fC}$ \\
\hline & GABO & $17.93 \pm 0.06 \mathrm{aE}$ & $19.78 \pm 0.03 \mathrm{bB}$ & $24.23 \pm 0.01 \mathrm{cD}$ & $24.74 \pm 0.02 \mathrm{dC}$ & $24.69 \pm 0.07 \mathrm{dD}$ & $25.35 \pm 0.01 \mathrm{eD}$ \\
\hline & EAEPO & $11.93 \pm 0.03 \mathrm{aB}$ & $20.13 \pm 0.02 b D$ & $21.11 \pm 0.02 \mathrm{cC}$ & $21.30 \pm 0.02 \mathrm{~dB}$ & $21.44 \pm 0.00 \mathrm{eB}$ & $21.65 \pm 0.01 \mathrm{fA}$ \\
\hline & HEBO & $10.57 \pm 0.02 \mathrm{aA}$ & $20.01 \pm 0.02 \mathrm{bC}$ & $20.03 \pm 0.02 b B$ & $21.36 \pm 0.02 \mathrm{cB}$ & $21.57 \pm 0.02 \mathrm{dC}$ & $22.54 \pm 0.01 \mathrm{eB}$ \\
\hline \multirow{5}{*}{ MUFA } & FGBO & $47.12 \pm 0.02 \mathrm{fCD}$ & $41.64 \pm 0.02 \mathrm{dC}$ & $41.11 \pm 0.01 \mathrm{cC}$ & $40.70 \pm 0.02 \mathrm{cB}$ & $41.78 \pm 0.04 \mathrm{eB}$ & $40.54 \pm 0.02 \mathrm{aC}$ \\
\hline & FBBO & $48.15 \pm 0.04 \mathrm{eD}$ & $47.43 \pm 0.02 \mathrm{dE}$ & $46.93 \pm 0.05 \mathrm{cE}$ & $47.65 \pm 0.49 \mathrm{cD}$ & $45.85 \pm 0.02 b C$ & $41.65 \pm 0.03 \mathrm{aD}$ \\
\hline & GABO & $45.97 \pm 0.01 \mathrm{eBC}$ & $45.13 \pm 0.03 \mathrm{dD}$ & $41.53 \pm 0.01 \mathrm{aD}$ & $41.55 \pm 0.04 c \mathrm{cC}$ & $41.86 \pm 0.08 \mathrm{cB}$ & $41.77 \pm 0.01 \mathrm{bE}$ \\
\hline & EAEPO & $44.48 \pm 0.04 \mathrm{cB}$ & $40.12 \pm 0.02 \mathrm{bB}$ & $39.28 \pm 0.04 \mathrm{abA}$ & $38.87 \pm 0.03 \mathrm{abA}$ & $38.53 \pm 0.02 \mathrm{abA}$ & $38.46 \pm 0.02 \mathrm{aA}$ \\
\hline & HEBO & $42.22 \pm 0.02 \mathrm{dA}$ & $39.98 \pm 0.02 \mathrm{cA}$ & $40.18 \pm 0.04 \mathrm{bB}$ & $39.30 \pm 0.58 \mathrm{cA}$ & $38.53 \pm 0.65 \mathrm{aA}$ & $38.74 \pm 0.02 \mathrm{abB}$ \\
\hline \multirow{5}{*}{ PUFA } & FGBO & $37.11 \pm 0.01 \mathrm{fC}$ & $31.46 \pm 0.02 \mathrm{eA}$ & $31.16 \pm 0.02 \mathrm{cA}$ & $30.63 \pm 0.02 \mathrm{cA}$ & $30.31 \pm 0.01 \mathrm{bA}$ & $27.96 \pm 0.02 \mathrm{aA}$ \\
\hline & FBBO & $36.29 \pm 0.03 \mathrm{eA}$ & $34.24 \pm 0.02 \mathrm{~dB}$ & $33.12 \pm 0.02 \mathrm{bB}$ & $33.14 \pm 0.03 \mathrm{bB}$ & $33.91 \pm 0.03 c \mathrm{c}$ & $32.95 \pm 0.04 \mathrm{aB}$ \\
\hline & GABO & $36.44 \pm 0.02 \mathrm{fB}$ & $35.65 \pm 0.01 \mathrm{eC}$ & $34.23 \pm 0.03 c \mathrm{c}$ & $33.73 \pm 0.03 c \mathrm{c}$ & $33.41 \pm 0.02 \mathrm{bB}$ & $32.95 \pm 0.01 \mathrm{aB}$ \\
\hline & EAEPO & $42.13 \pm 0.03 \mathrm{dD}$ & $39.54 \pm 0.02 \mathrm{aD}$ & $39.58 \pm 0.03 \mathrm{aD}$ & $39.73 \pm 0.05 \mathrm{bE}$ & $39.74 \pm 0.03 \mathrm{bE}$ & $39.84 \pm 0.03 \mathrm{cD}$ \\
\hline & HEBO & $45.64 \pm 0.02 \mathrm{fE}$ & $39.97 \pm 0.01 \mathrm{dE}$ & $40.18 \pm 0.04 \mathrm{dE}$ & $38.96 \pm 0.02 \mathrm{cD}$ & $38.89 \pm 0.02 \mathrm{bD}$ & $38.74 \pm 0.02 \mathrm{aC}$ \\
\hline
\end{tabular}

Mean values within each row followed by different letters $(\mathrm{a}, \mathrm{b}, \mathrm{c}$, etc.) are significantly $(P<0.05)$ different. Mean values within each column followed by different letters $(\mathrm{A}, \mathrm{B}, \mathrm{C}$, etc.) are significantly $(P<0.05)$ different.

induce modification of fatty acids that contain two or three double bonds. Both oxidation and oxidative polymerization occur with progressive heating. Furthermore, the relative oxidation rate of linolenic acid is much higher than that of stearic acid [24].
The fatty acid ratio of EAEPO and HEBO (0.27: $1.03: 0.96$ and $0.27: 1.08: 1.16)$ approached the ideal fatty acid ratio of $0.27: 1: 1$ (SFA : MUFA : PUFA), as shown in Table 5; the other three kinds of blended oils also approached this ratio prior to heating $(0.27: 0.65: 0.8,0.27: 0.6: 0.84$, and $0.27: 0.61: 0.79$ 
TABLE 5: Variation of SFA : MUFA : PUFA ratio of blended oils.

\begin{tabular}{lcccccc}
\hline & \multicolumn{5}{c}{ SFA, MUFA, and PUFA } \\
& $0 \mathrm{~h}$ & $1 \mathrm{~h}$ & $2 \mathrm{~h}$ & $4 \mathrm{~h}$ & $6 \mathrm{~h}$ & $8 \mathrm{~h}$ \\
\hline FGBO & $0.27: 0.65: 0.8$ & $0.27: 0.42: 0.32$ & $0.27: 0.40: 0.30$ & $0.27: 0.38: 0.29$ & $0.27: 0.41: 0.29$ & $0.27: 0.35: 0.24$ \\
FBBO & $0.27: 0.6: 0.84$ & $0.27: 0.70: 0.50$ & $0.27: 0.64: 0.45$ & $0.27: 0.64: 0.45$ & $0.27: 0.61: 0.45$ & $0.27: 0.44: 0.35$ \\
GABO & $0.27: 0.61: 0.79$ & $0.27: 0.62: 0.49$ & $0.27: 0.46: 0.38$ & $0.27: 0.45: 0.37$ & $0.27: 0.45: 0.35$ & $0.27: 0.45: 0.35$ \\
EAEPO & $0.27: 1.03: 0.96$ & $0.27: 0.54: 0.53$ & $0.27: 0.49: 0.50$ & $0.27: 0.48: 0.50$ & $0.27: 0.48: 0.50$ & $0.27: 0.48: 0.49$ \\
HEBO & $0.27: 1.08: 1.16$ & $0.27: 0.51: 0.54$ & $0.27: 0.50: 0.54$ & $0.27: 0.47: 0.49$ & $0.27: 0.46: 0.49$ & $0.27: 0.43: 0.46$ \\
\hline
\end{tabular}

TABLE 6: Changes in trans-fatty acid profile $(\mathrm{mg} / \mathrm{mL})$.

\begin{tabular}{lcccccc}
\hline & \multicolumn{5}{c}{ TFAs } & \\
& $0 \mathrm{~h}$ & $1 \mathrm{~h}$ & $2 \mathrm{~h}$ & $4 \mathrm{~h}$ & $6 \mathrm{~h}$ & $8 \mathrm{~h}$ \\
\hline FGBO & $0.01 \pm 0.01 \mathrm{aA}$ & $4.94 \pm 0.01 \mathrm{bA}$ & $17.18 \pm 0.02 \mathrm{cA}$ & $59.68 \pm 0.03 \mathrm{dA}$ & $157.83 \pm 0.08 \mathrm{eA}$ & $280.16 \pm 0.18 \mathrm{fA}$ \\
$\mathrm{FBBO}$ & $0.01 \pm 0.04 \mathrm{aC}$ & $5.78 \pm 0.03 \mathrm{bC}$ & $21.32 \pm 0.01 \mathrm{cC}$ & $68.79 \pm 0.04 \mathrm{dC}$ & $188.48 \pm 0.03 \mathrm{eC}$ & $257.14 \pm 0.08 \mathrm{fC}$ \\
$\mathrm{GABO}$ & $0.01 \pm 0.01 \mathrm{aB}$ & $5.07 \pm 0.06 \mathrm{bB}$ & $18.54 \pm 0.05 \mathrm{cB}$ & $64.61 \pm 0.08 \mathrm{~dB}$ & $162.39 \pm 0.03 \mathrm{eB}$ & $333.44 \pm 0.09 \mathrm{fB}$ \\
EAEPO & $0.02 \pm 0.01 \mathrm{aD}$ & $9.55 \pm 0.03 \mathrm{bD}$ & $29.88 \pm 0.05 \mathrm{cD}$ & $88.64 \pm 0.02 \mathrm{dD}$ & $232.52 \pm 0.07 \mathrm{eD}$ & $542.39 \pm 0.08 \mathrm{fD}$ \\
HEBO & $0.02 \pm 0.01 \mathrm{aC}$ & $12.43 \pm 0.02 \mathrm{bE}$ & $30.51 \pm 0.03 \mathrm{cE}$ & $93.09 \pm 0.037 \mathrm{dE}$ & $256.70 \pm 0.06 \mathrm{eE}$ & $558.60 \pm 0.14 \mathrm{fE}$ \\
\hline
\end{tabular}

Mean values within each row followed by different letters (a, b, c, etc.) are significantly $(P<0.05)$ different. Mean values within each column followed by different letters $(\mathrm{A}, \mathrm{B}, \mathrm{C}$, etc.) are significantly $(P<0.05)$ different.

for FGBO, FBBO, and GABO, resp.). At the end of the heating time, the ratio was $0.27: 0.48: 0.49$ for EAEPO, which indicates that a relatively close to ideal fatty acid ratio for a healthy diet could be maintained for the EAEPO sample as heating progressed.

3.6. Changes in Trans-Fatty Acids. Epidemiological evidence has suggested that the level of trans-fatty acid (TFA) intake is connected to the risk of cardiovascular disease [25]; thus, there have been several studies on TFAs contained in food materials. The amount of total TFAs in the evaluated oil types was in the range of $0.01-0.02 \mathrm{mg} / \mathrm{mL}$, which clearly approximates the requirement for a "zero trans" content. However, a substantial increase in the TFAs of the various oils was observed when the oils were heated for $6 \mathrm{~h}$ to $8 \mathrm{~h}$ (Table 6). At the final heating time, EAEPO and HEBO presented the highest total TFA content. Several factors, such as the FA composition of each oil and coexisting antioxidants, may contribute to the variation in the thermal TFA accumulation profiles [26].

\section{Conclusions}

The results of this study demonstrate that the quality of enzyme-assisted aqueous processing extracted blended oil (EAEPO) is superior to that of hexane-extracted blended oil (HEBO) from the initial to the final heating time, which is possibly due to the extraction method of the former that utilizes water as an extraction and separation medium thereby maintaining a higher antioxidant content. However, compared to the other three refined oil samples, the EAEPO and HEBO samples were less stable towards oxidative degradation. Nevertheless, EAEPO was found to have the lowest acid value and offers the additional advantage of containing an ideal fatty acid ratio after heat treatment of the oils $(0.27: 0.48: 0.49)$, which has been linked to reduced risk of high cholesterol and heart disease. The advantageous characteristics may be attributed to the superior initial fatty acid composition of EAEPO.

\section{Conflict of Interests}

The authors declare that there is no conflict of interests regarding the publication of this paper.

\section{Authors' Contribution}

Lianzhou Jiang and Yang Li contributed equally to this paper.

\section{Acknowledgments}

The authors are grateful to the National High-Tech R\&D Program of China (863 Program) (no. 2013AA102104), the Key Laboratory of Soybean Biology of the Chinese Education Ministry, Northeast Agricultural University (no. SB12C01), the Establishment of Modern Agricultural R\&D Systems (no. Nycytx-004), and the National Research Center of Soybean Engineering and Technology for support of this project. The authors are also grateful to the anonymous referees for helpful comments on an earlier draft. 


\section{References}

[1] Y. Li, Y. Zhang, M. Wang, L. Jiang, and X. Sui, "Simplex-centroid mixture design applied to the aqueous enzymatic extraction of fatty acid-balanced oil from mixed seeds," Journal of the American Oil Chemists' Society, vol. 90, no. 3, pp. 349-357, 2013.

[2] Interim Summary of Conclusions and Dietary Recommendations on Total Fat \& Fatty Acids. From the Joint FAO/WHO Expert Consultation on Fats and Fatty Acids in Human Nutrition, WHO, Geneva, Switzerland, 2008.

[3] Chinese Nutrition Society, Chinese Dietary Reference Intakes (DRIs), China Light Industry Press, Beijing, China, 2000.

[4] Q. Zhang, A. S. M. Saleh, J. Chen, and Q. Shen, "Chemical alterations taken place during deep-fat frying based on certain reaction products: a review," Chemistry and Physics of Lipids, vol. 165, no. 6, pp. 662-681, 2012.

[5] S. Debnath, N. K. Rastogi, A. G. Gopala Krishna, and B. R. Lokesh, "Effect of frying cycles on physical, chemical and heat transfer quality of rice bran oil during deep-fat frying of poori: an Indian traditional fried food," Food and Bioproducts Processing, vol. 90, no. 2, pp. 249-256, 2012.

[6] R. Malheiro, S. Casal, H. Lamas, A. Bento, and J. A. Pereira, "Can tea extracts protect extra virgin olive oil from oxidation during microwave heating?" Food Research International, vol. 48, no. 1, pp. 148-154, 2012.

[7] A. F. Valdés and A. B. Garcia, "A study of the evolution of the physicochemical and structural characteristics of olive and sunflower oils after heating at frying temperatures," Food Chemistry, vol. 98, no. 2, pp. 214-219, 2006.

[8] W. H. Liu, B. Stephen Inbaraj, and B. H. Chen, "Analysis and formation of trans fatty acids in hydrogenated soybean oil during heating," Food Chemistry, vol. 104, no. 4, pp. 1740-1749, 2007.

[9] N. Rodrigues, R. Malheiro, S. Casal, M. C. Asensio-SManzanera, A. Bento, and J. A. Pereira, "Influence of spike lavender (Lavandula latifolia Med.) essential oil in the quality, stability and composition of soybean oil during microwave heating," Food and Chemical Toxicology, vol. 50, no. 8, pp. 28942901, 2012.

[10] E. Chiavaro, C. Barnaba, E. Vittadini, M. T. Rodriguez-Estrada, L. Cerretani, and A. Bendini, "Microwave heating of different commercial categories of olive oil-part II: effect on thermal properties," Food Chemistry, vol. 115, no. 4, pp. 1393-1400, 2009.

[11] S. Marmesat, A. Morales, J. Velasco, and M. Carmen Dobarganes, "Influence of fatty acid composition on chemical changes in blends of sunflower oils during thermoxidation and frying," Food Chemistry, vol. 135, no. 4, pp. 2333-2339, 2012.

[12] Y. Li, L. Jiang, and G. Qiao, "Effect of extruding parameters on soybean oil yield of enzyme-assisted aqueous extraction processing," Advanced Materials Research, vol. 148-149, pp. 7-18, 2011.

[13] Y. Li, L. Jiang, Z. Zhang et al., "Fuzzy optimization of enzyme assistant aqueous for extracting oil and protein from extruded soybean," Transactions of the Chinese Society of Agricultural Engineering, vol. 26, no. 2, pp. 375-380, 2010.

[14] R. B. Pegg, "Measurement of primary lipid peroxidation products (D2.1.1-D2.1.15)," in Current Protocols in Food Analytical Chemistry, John Wiley \& Sons, New York, NY, USA, 2001.

[15] R. A. Moreau, D. B. Johnston, M. J. Powell, and K. B. Hicks, "A comparison of commercial enzymes for the aqueous enzymatic extraction of corn oil from corn germ," Journal of the American Oil Chemists' Society, vol. 81, no. 11, pp. 1071-1075, 2004.
[16] S. M. Abdulkarim, K. Long, O. M. Lai, S. K. S. Muhammad, and H. M. Ghazali, "Frying quality and stability of high-oleic Moringa oleifera seed oil in comparison with other vegetable oils," Food Chemistry, vol. 105, no. 4, pp. 1382-1389, 2007.

[17] S. Casal, R. Malheiro, A. Sendas, B. P. P. Oliveira, and J. A. Pereira, "Olive oil stability under deep-frying conditions," Food and Chemical Toxicology, vol. 48, no. 10, pp. 2972-2979, 2010.

[18] Codex Alimentarius Commission, Codex-Stan 210: Codex Standard for Named Vegetable Oils, Food and Agriculture Organization, Rome, Italy, 2008.

[19] S. Latif and F. Anwar, "Effect of aqueous enzymatic processes on sunflower oil quality," Journal of the American Oil Chemists' Society, vol. 86, no. 4, pp. 393-400, 2009.

[20] F. Shahidi and U. N. Wanasundara, "Methods for measuring oxidative rancidity in fats and oils," in Food Lipids: Chemistry, Nutrition, and Biotechnology, pp. 377-396, 2002.

[21] M. Laguerre, J. Lecomte, and P. Villeneuve, "Evaluation of the ability of antioxidants to counteract lipid oxidation: existing methods, new trends and challenges," Progress in Lipid Research, vol. 46, no. 5, pp. 244-282, 2007.

[22] S. Lalas, O. Gortzi, and J. Tsaknis, "Frying stability of Moringa stenopetala seed oil," Plant Foods for Human Nutrition, vol. 61, no. 2, pp. 99-108, 2006.

[23] G. Bansal, W. Zhou, P. J. Barlow, H.-L. Lo, and F.-L. Neo, "Performance of palm olein in repeated deep frying and controlled heating processes," Food Chemistry, vol. 121, no. 2, pp. 338-347, 2010.

[24] A. H. Ahmad Tarmizi, K. Niranjan, and M. Gordon, "Physicochemical changes occurring in oil when atmospheric frying is combined with post-frying vacuum application," Food Chemistry, vol. 136, no. 2, pp. 902-908, 2013.

[25] F. A. Aladedunye and R. Przybylski, "Degradation and nutritional quality changes of oil during frying," Journal of the American Oil Chemists' Society, vol. 86, no. 2, pp. 149-156, 2009.

[26] W. Tsuzuki, A. Matsuoka, and K. Ushida, "Formation of trans fatty acids in edible oils during the frying and heating process," Food Chemistry, vol. 123, no. 4, pp. 976-982, 2010. 

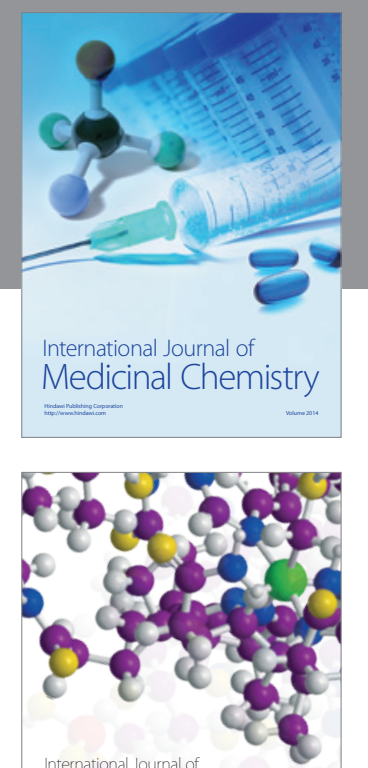

\section{Carbohydrate} Chemistry

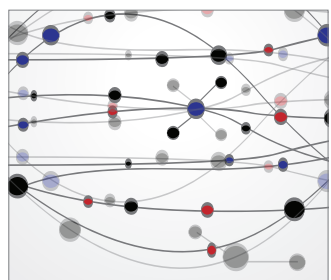

The Scientific World Journal
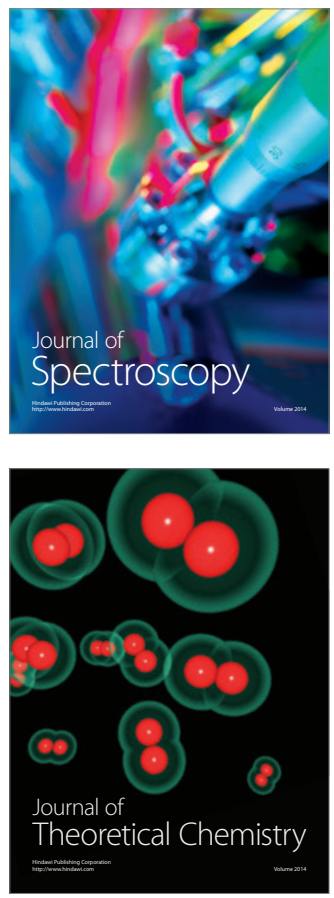
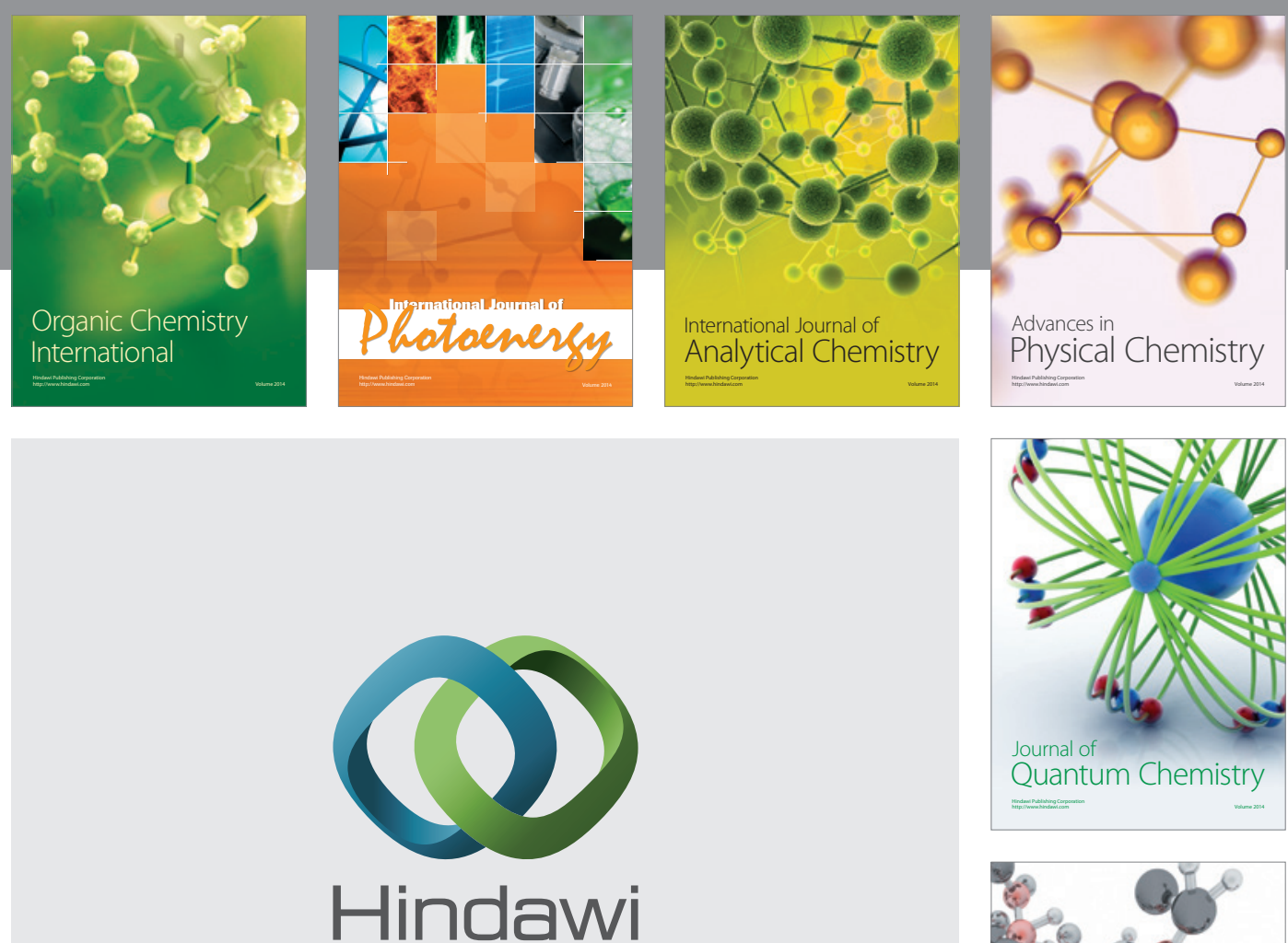

Submit your manuscripts at

http://www.hindawi.com

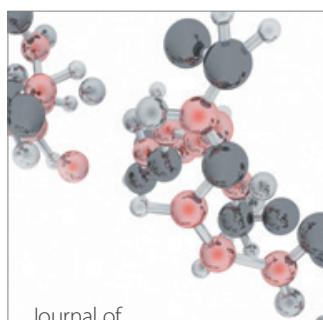

Analytical Methods

in Chemistry

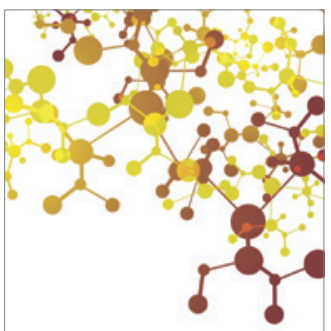

Journal of

Applied Chemistry

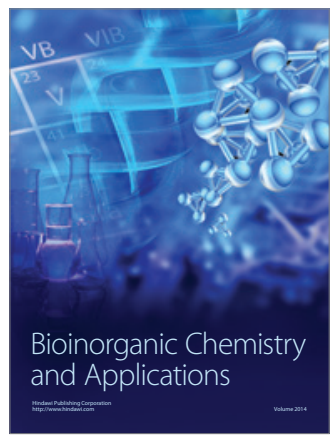

Inorganic Chemistry
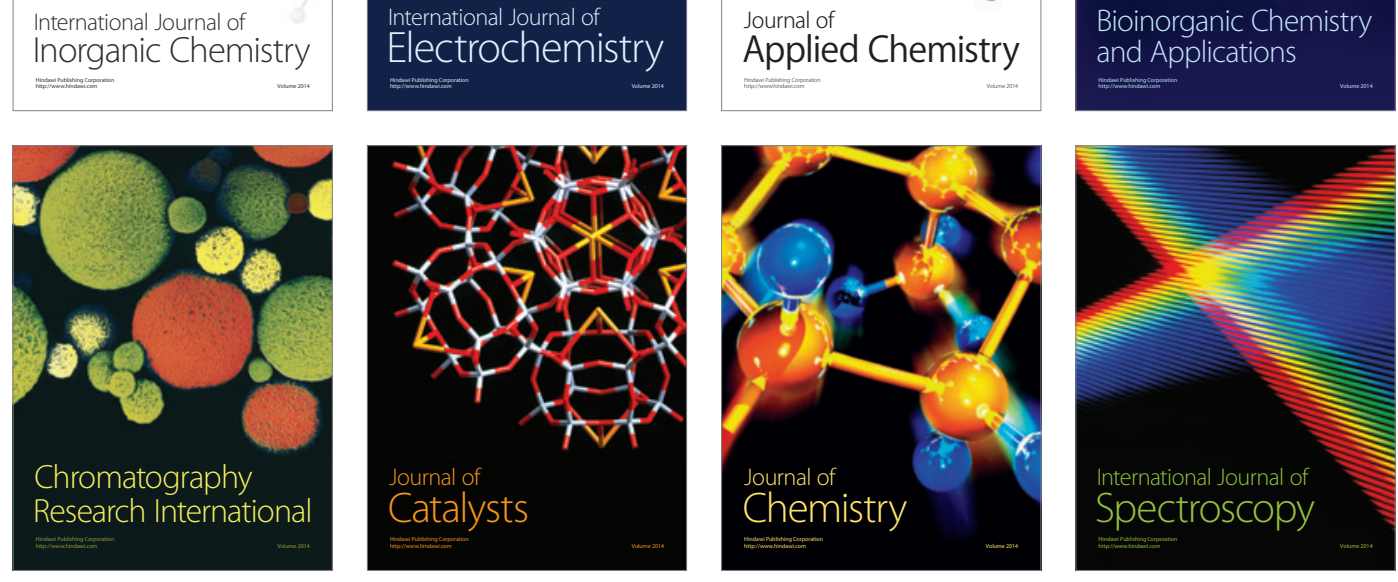